\title{
From Concrete Poetry to Musical Composition: Narrativity, Intertextuality and Musical Meaning in Motet em Ré Menor, by Gilberto Mendes
}

\author{
Da Poesia Concreta à Composição Musical: \\ Narratividade, Intertextualidade e Significação Musical \\ em "Motet em Ré Menor", de Gilberto Mendes
}

\author{
André Lopes Martins \\ University of São Paulo \\ andremarttins@usp.br
}

\section{Rogério Costa}

University of São Paulo

rogercos@usp.br

\begin{abstract}
This paper intends to construct some reflections on how the use of the poetic text as process of creation of a musical composition can be developed through the rhythmic, sonorous and melodic use of the words, verses and their (possible) musical meaning. Specifically, we use the example of the choral piece Motet em Ré Menor (1966), by the Brazilian composer Gilberto Mendes (1922-2017), a composition based on the concrete poem Beba Coca-Cola (1958) by Décio Pignatari (1927-2012). Some of the problems and issues related to the processes of narrativity and intertextuality, topical meaning and tropification - from the idea of musicking this poem - will be listed and approached in a reflection based on a musical analysis that seeks to depart from the form to the musical meaning relevance.

Keywords: musical analysis; musical meaning; concrete poetry; musical narrative; intertextuality.
\end{abstract}

Resumo: Este artigo pretende construir algumas reflexões em como o uso de um texto poético como ferramenta de criação musical pode ser desenvolvido a partir do uso rítmico, sonoro e melódico de suas palavras, versos e sua possível significação. Especificamente, utilizamos o exemplo da peça coral Motet em Ré Menor (1966), do compositor santista Gilberto Mendes (19222017), composto a partir do poema concreto Beba Coca-Cola (1958), de Décio Pignatari (1927-2012). Alguns dos problemas e das questões relacionadas com os processos de narratividade e intertextualidade, significação tópica e tropificação - a partir da ideia de musicar este poema -, serão elencados e abordados em uma reflexão a partir de uma análise musical que procura partir da forma para a relevância da significação musical.

Palavras-chave: análise musical; significação musical; poesia concreta; narratividade musical; intertextualidade. 


\section{1 - Introduction}

Gilberto Mendes composed Motet em Ré Menor in 1967, during what is considered his experimental phase, after the concrete poem Beba Coca-Cola (1958), by Décio Pignatari. Mendes sought to (re)create several rhythmic, phonetic and melodic possibilities that already existed in the original poem and to build a bridge for the exercise of singing, through a polyphonic motet. Within this reading, which are the narrative resources that the composer sought to allocate? Which are the text forms and intertextual relations that are possible to be "read" in the composition of Mendes? (Which would be the forms of narrative and intertextuality in Pignatari's poem that would be possible to listen to?). Moreover, how does the composer from Santos approach the semiotic meanings that underlie the original poem used for its composition? We seek in this article to develop some reflections on these subjects and contribute to the study of a narrative, intertextual and musical analysis of the repertoire of Brazilian contemporary music.

\section{2 - Concrete Poetry}

Concrete poetry began in Brazil in the 50's of the twentieth century, as an avant-garde movement, in literature, in the plastic arts, fostering also a strong proximity to contemporary music. The idea of concrete poetry comes from the concretist movement of the 1930s, where plastic artists seek to conceptualize the idea of a concrete art - starting from definitive forms and their adherences - as opposed to an abstract art. According to Correa (2011, p. 63), "concrete poetry proposes a change in the international literary scene from the 1950s ... in which the poem should be constructed in a synthetic-ideographic way." The concrete poem makes use of the blank space (or any other color that is present in the free space of the page) of the page's own format, typology, characters $\left(,-,<,>,,^{\prime} \wedge^{\prime}\right.$,

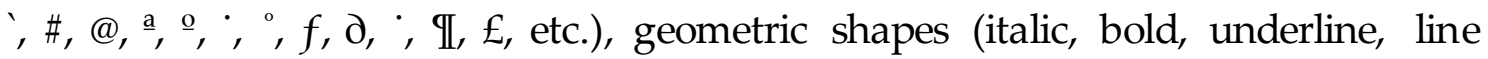
spacing, etc.), and everything that may be understood as being or becoming verbivocovisual ${ }^{1}$. The manifesto Plano-piloto para poesia concreta ${ }^{2}$, published in São

\footnotetext{
${ }^{1}$ Term that gives equal importance to the written word, orality and the graphic aspect of a text, where visuality and audibility are always related to the linguistic form. "The Joycean expression verbivocovisual synthesizes the proposal that, since the 1950s, was put into practice by the poets Augusto de Campos, Décio Pignatari, Haroldo de Campos, José Lino Grünewald and Ronaldo Azeredo unfolding to this day, and spaning over more than five decades, a large production in various media and media - book, magazine, newspaper, poster, object, $l p, c d$, videotext, holography, video and internet". (http://www.poesiaconcreta.com.br/poetas.php - access in June 20, 2017).

${ }^{2}$ Available in Portuguese at:
}

\section{MUSICA THEORICA}


Paulo in 1958, co-signed by Haroldo de Campos, his brother Augusto de Campos and Décio Pignatari, preaches the use of the page space as structural agent (i.e., the poem communicates its own structure), paronomasia and the end of verse as the rhythmic/formal unity of the poetry. The concretist movement embraces links with the visual arts, contemporary music, design and electronic media, such as radio, TV, electronic sound recording and cinema, among others. Concretism bears the influence of the aesthetic work of precursor artists such as Oswald de Andrade, Stéphane Mallarmé, Ezra Pound, James Joyce, Edward Estlin Cummings (e.e. cummings), among others. Perhaps one of the most elucidative definitions of concrete poetry is the one that introduces the manifesto. It is signed by the three concrete poets from Sao Paulo (the Campos brothers and Pignatari) and defines in its first paragraph:

Concrete poetry: the product of a critical evolution of forms ending the historical cycle of verse (formal rhy thmic unity), concrete poetry begins by acknowledging the graphic space as a structural agent. Qualified space: spatial-temporal structure, rather than merely temporistic-linear development, hence the importance of the idea of ideogram, from its general sense of spatial or visual syntax, until its specific sense (Fenollosa/Pound) of compositional method based on direct - analogical, non logical-discursive-juxtaposition of elements. "Il faut that notre intelligence s'habitue à comprendre synthético-ideographiquement au lieu de analytico-discursivement" (Apollinaire). Eisenstein: ideogram and montage ${ }^{3}$.

Décio Pignatari, author of Beba Coca-Cola, is one of the main Brazilian concrete poets, who helped define the movement along with the Campos brothers. Pignatari wrote Beba Coca-Cola in the mid-1950s, at a post-Second War moment, when he considered that the US practiced a form of capitalist and expansionist imperialism that appeared increasingly prominent and radical. It was the birth of the Cold War, in a polarized capitalist against communist world, US $x$ Soviet Union. In that context, perhaps one of the most striking symbols of American culture in the mid-twentieth century is the Coca-Cola soft drink. Specifically about the poem written by Pignatari, Menezes (1998, p. 100) states that

http://tropicalia.com.br/en/leituras-complementares/plano-piloto-para-poesia-concreta - access on June 20, 2017.

${ }^{3}$ In Portuguese, according to the original text: "poesia concreta: produto de uma evolução crítica de formas dando por encerrado o ciclo histórico do verso (unidade rítmico-formal), a poesia concreta começa por tomar conhecimento do espaço gráfico como agente estrutura. Espaço qualificado: estrutura espácio-temporal, em vez de desenvolvimento meramente temporísticolinear, daí a importância da idéia de ideograma, desde o seu sentido geral de sintaxe espacial ou visual, até o seu sentido específico (Fenollosa/Pound) de método de compor baseado na justaposição direta - analógica, não lógico-discursiva - de elementos. "Il faut que notre intelligence s'habitue à comprendre synthético-ideographiquement au lieu de analytico-discursivement" (Apollinaire). Eisenstein: ideograma e montagem" - Our translation to English. 


\begin{abstract}
we may see the preoccupation with themes of modern life, in the form of criticism of the American capitalism; it is not strictly geometric, but its text is worked within the structure of mathematical permutation of the letter order of the CocaCola slogan.
\end{abstract}

The concretists often use some quite clear and somewhat rigid internal rules of composition, as an axis for displacement of letters, phonemes and words, visual representation, the use of space, symbols and signs. All of them helps to brake the rhythmic formality of the verse and dispenses the use of rhyme, replacing it by horizontal, vertical and diagonal movements, among other resources. Notwithstanding, Pignatari manages to synthesize, not surprisingly, an evaluation of the subliminal content of what it means to drink Coca-Cola, viscerally impressing a repudiation of this consuming act, as illustrated in Figure 1.

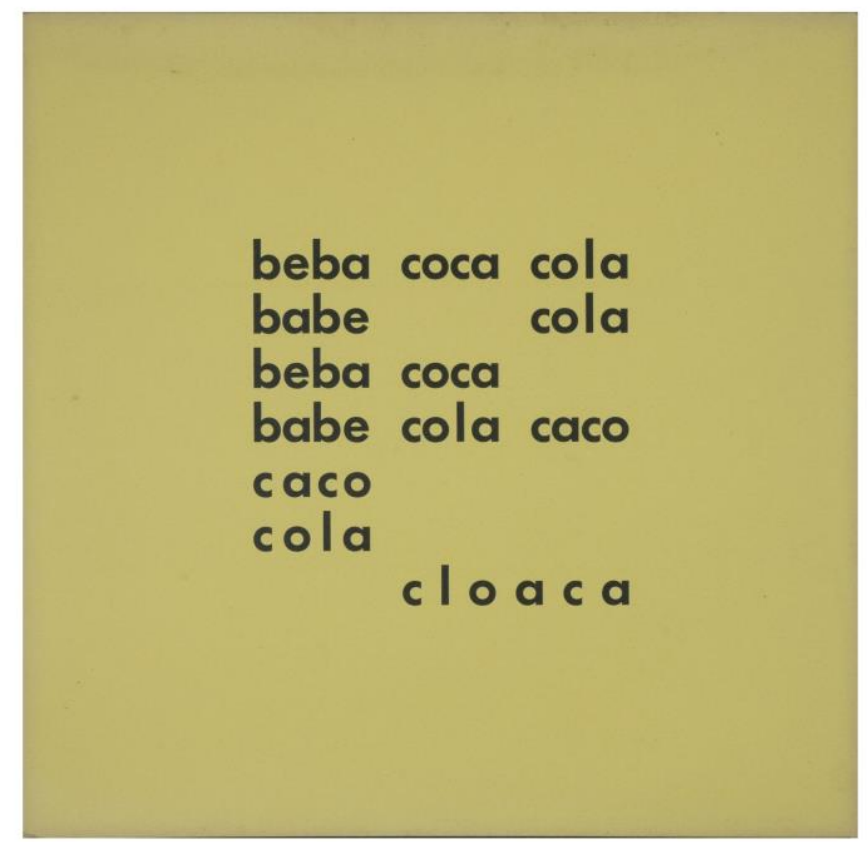

Figure 1: Original poem Beba Coca-Cola, by Décio Pignatari, 1957

It is possible to perceive the cross-rhythm between the words beba and babe, the phonetic repetition of cola and, mainly, the cacophony between the fourth and fifth lines of the poem, in cola caco / caco / cola. It also suggests the idea of an anti-propaganda - as Haroldo de Campos writes (1975, p.83), "the poem of Pignatari is an example of the use of the techniques of concrete poetry for an advertisement - or anti-propaganda - on the basis of Maiacovski's aguit-placat". The seventh and last line of the poem discourages all built-in rhythm and purposely destroys any verisimilitude or paranomasia with the word cloaca. 
Nevertheless, it suggests the meaning unwashed, sewer, latrine, stye, which encompasses the idea of excrement, of remains, of that which no longer serves us or has no use. It is here that Pignatari constructs the climax of his criticism to the imperialistic model, to the unbridled consumption that has no use to anything and anyone, except to the capitalist world. Being the only word / line positioned at the right of the poem, Pignatari imprints on the paper an overwhelming sense of ending, that something really arrives at its existential destination and that what is left are only remnants, trash, nothing helpful. As we shall see later, Mendes solves the musical form for this text allocating the word cloaca in the last measure, in a syllabic and ternary division, in fortissimo. Interestingly, many choirs chose to perform a kind of rereading of this moment, bringing the word cloaca written in a banner or through some body statement, proposing a performance within a performance: like some of the singers lifting their shirt and presenting the word written on their own bodies. It is worth mentioning that the word cloaca contains within it all the letters that form the three of the main words of the poem: cola, coca, and caco.

Thus, concrete poetry breaks the standards established by traditional poems, presenting a new concept of poetic composition, where even notions such as beginning-middle-end tend to disappear. The Campos brothers and Pignatari reveal (1975, p.18): "it is, therefore, a dynamic use of typographic resources already impotent in their routine arrangement to serve the full range of inflections that a poetic thinking is capable of." By (re)visiting some of the most important theoretical works and poems of the concrete movement (as Se, or Nasce-Morre, by Haroldo de Campos, Cristal by H. de Campos, Beba Coca-Cola by D. Pignatari, Galáxias by A. de Campos, Poetamentos by A. de Campos, Mar Azul by Ferreira Gullar and Escreviver by J. L. Grünewald), it becomes clear that the dynamic use of resources of various types (visual, sound, typographic, media support, white space, emptiness, geometry, etc.) allows the awakening of new paradigms of creation and reflection about what a poetic thought is capable of. The concrete poems have a rhizomatic character ${ }^{4}$, forming branches, limbs and boughs, overlapping roots, extensions that always suggest pertinence to a net of relations and significations between them.

\footnotetext{
4 The concept of rhizome was developed by the French philosophers Gilles Deleuze and Felix Guattari in A Thousand Plateaus (1993). For Due (2007, p. 133), "the term 'rhizome' originally refers to a widely spreading tree root. Here the concept of the rhizome is an ordered set of relations in which each element relates to every other, without any hierarchical, functional or centralized order being imposed on these relations. This rhizomatic principle of fluid systems and relations now opposes the organizing principles of state rule, as immanence opposes transcendence". In reality, it is an environment, a netw ork of relationships. Rhizome is a form of open relationships that can cut paths; are lines of escape and intensity that makes contact with other roots; follow in other directions, not being a form of closed relationship.
} 


\title{
3 - Short Analysis of Motet em Ré Menor
}

The Motet em Ré Menor, also known as Beba Coca-Cola, is a composition for mixed choir based on the homonymous concrete poem of Décio Pignatari. Mendes names the composition a motet form, one of the most traditional genres of polyphonic vocal music, used by composers from the 13th century through the contemporary period. It does not have a fixed form and is based in one or more texts for each vocal parts.

Mendes' Motet is a work that belongs to the experimental / avant-garde period of the composer. For Magre and Berg (2015), "Mendes organizes the Pignatari's text, except for the word cloaca, in a constant and uninterrupted pulse, in rapid progress, giving fluidity to the music". Mendes rewrites the original concrete division from Pignatari's poem, enhancing the four different phonemes originally presented in the 1957 poem:

\author{
beba coca cola \\ babe cola \\ beba coca \\ caco caco cola
}

Mendes builds a figuration of contrapuntal characteristics, based on a strong marked rhythm that, nevertheless is, at the same time, submerged by the choral arrangement. As the composer himself states, "I glanced at the poem and immediately felt the Renaissance counterpoint on it, still with a slight touch of fresh air, the quick, incisive lines formed by the words" (Mendes, 2016, p.102). The piece presents some experimental procedures such as microtonalisms, exaggerated intonation, sung and spoken vocal lines, glissandos that cross several bars and even a burp, a key moment of the composition. It cues the entry of a kind of Coda that uses a deliberately swing rhythm to deliver a spoken line. That section reminds us of a very popular song at the time, named Deixa isso pra lá, that was recorded around 1965 by Jair Rodrigues, on a live album named Dois na Bossa, together with the famous singer Elis Regina, who was still at the beginning of her career. Deixa isso pra lá brought to the Brazilian popular music a more rhythmic and a spoken way of singing that anticipated a few decades the Rap ${ }^{5}$ music style. Mendes borrows the style and feeling of that original pop rhythm to place the mood of his choral piece in an ironic and even sarcastic tone.

\footnotetext{
${ }^{5}$ According to the site http://ww w.dictionary.com, Rap (for some critics, an acronym for rhyth $m$ and poetry), "is a style of popular music, developed by disc jockeys and urban blacks in the late 1970s, in the US, in which an insistent, recurring beat pattern provides the background and counterpoint for rapid, slangy, and often boastful rhyming patter glibly intoned by a vocalist or vocalists".
} 
Mendes sarcasm also responds to some of the issues that Pignatari's own concrete poem already brought forth: the symbolic image of the Beba Coca-Cola slogan and its mercantilist, capitalist and implied cultural values. We must highlight that the year of the composition also coincides with one of the most violent moments of Brazilian history. The echoes of the 1964 military coup that deposed the democratically elected president João Goulart were still on the air. Mendes, since his youth, throughout his life, remained an engaged leftist.

On the other hand, we may remember that between 1962 and 1968, Mendes attended the Darmstadt summer camps in Germany, a center of reference for the production of new music spreading a new artistic aesthetic. In Darmstadt, Mendes attended classes of Henri Pousseur, Pierre Boulez and Karlheinz Stockhausen, among many others, and, inspired/influenced by this movement and its original knowledge, Mendes approaches the Noigandres ${ }^{6}$ group of poets. As Santos (1997, p. 33) states, "the rapprochement with the Noigandres group stimulates Mendes in the search for a new musical language based on concrete poetry"7.

The translation of the slogan Drink Coca-Cola to Portuguese, not only allowed a literal translation of the meaning but also enhanced the phonetic, extending the creation into new symmetrical combinations. Pignatari's own poem demonstrates this by proposing a duality of meanings in:

\section{Beba Coca \\ Babe Cola}

The English translation of babe cola would be something like to drool coke, in the sense of salivating, dropping liquid out of the mouth. However, in Portuguese, there is also another possible meaning for the word drool. In the Brazilian slang, the word has a pejorative connotation, implying that a person, who drinks it, consumes the product without questioning, without reflecting, i.e. consumes it because it is fashionable, in vogue at that moment. Pignatari, creating this phonetic paradigm, not only combines the poetic possibilities between the syllables present in the original soda slogan, but also, at the same time, strongly

\footnotetext{
${ }^{6}$ The Noigandres group was one of the earliest artist collectives in the concrete movement, which spanned, not only literature, but also music, painting, and sculpture. Challenging traditions of artistic form and meaning, the concrete movement began in the 1950s by abstracting language, visual form, and their dual comprehension. The poets Haroldo de Campos, Augusto de Campos, and Décio Pignitari formed the Noigandres group, which takes its name from a neologism found in an Ezra Pound poem, in 1952. See: http://avant.org/event/noigandres/- access in June 20, 2017. ${ }^{7}$ For a better understanding of Mendes musical language we recommend to listen to some of his most important compositions, for instance interpreted by the Brazilian pianist Thais Nicolau as in Urubuqueaçaba (https://www.youtube.com/watch?v=ZufVlCj7ih8) and Saudades do Parque Balneário Hotel (https://www.youtube.com/watch?v=BcJtCYLuo30) - access in July 4th, 2017.
} 
criticizes uncontrolled habits of consumption and Coca-Cola as a symbol of imperialism. In the poem, there is also the repetition of the word caco that alludes to a piece of broken glass of a Coca-Cola bottle. The poem also metaphorically asks: "when having a soda drink, what is the person actually drinking?" And it answers: he drinks cacos (shards) of glass that, in addition to being deadly, represent an act of cultural contamination. What Pignatari did, with very few changes on the original English text of the Coca-Cola slogan, is to address the issue of a society of consumers and the unreflected importation of American cultural values by the Brazilian society.

Motet em Ré Menor assigns only five pitches for its four voices: E flat for the sopranos, D for the tenors, A for the contraltos, and G sharp or F for the basses. These notes are stacked as a cluster, producing a rigid, dissonant harmony that ends up not presenting any fluid harmonic direction or cadencial movement. Example 2 shows the chord formed by these five notes, which permeates the whole piece.

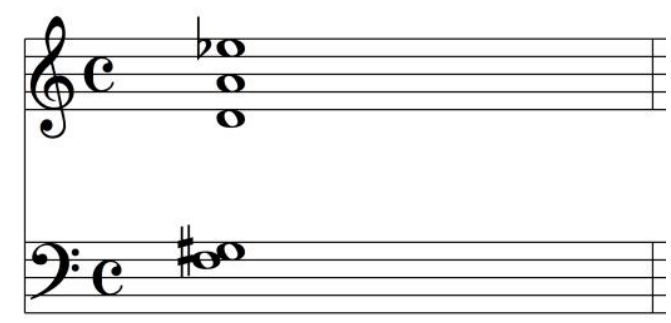

Example 2: Mendes' Motet em Ré Menor basic chord

For each voice is allocated a single note, but for the basses Mendes writes two notes, G\# and F, although the latter is sung on only two measures. Each voice allows variation of octave, in a constant back-and-forth. The result seems blocked and apparently static, but on the other hand allows glissandos, nasal timbre variations and breath ornaments. The composer instruction notes for the performers, as they appear in the score published by The New Consonant Music, elicit a series of important effects, among them: each singer is allowed some degree of freedom (that produces an effect of almost randomness), starting on his or her central register; the resulting fourth voices sound complex can sometimes allow microtonal interval relationships between individual voices; spoken sounds and texts are also used, with dramatic intonation and accentuations in the variations of the frequencies, with expressions of surprise, indignation, warning, distress, etc.

Magre and Berg (2015) recognize several different sections in this composition, each with its own characteristics. For these authors, from the first to the 13th measure there is a section " $\mathrm{A}$ " which introduces the material of each 
voice. It is also the only moment in which the basses sing the pitch $\mathrm{F}$ (measures 5 and 6). In the rest of the piece, the bass performs several variations but on the pitch $G$ sharp, using the range of an octave. We prefer to use the division proposed by the composer himself (Mendes 2016, p.104), who sees the piece as composed "always in six-bar blocks with beats 3-2-2-2-2-2-1". This results in a more rigid unit of blocks with minimalistic variations. Example 3 shows the first page of the Motet. Wehighlighted the first two blocks, of six bars each. The orange color represents block 1 and the pink color represents block 2. This kind of block division occurs throughout the composition, with minimal expressive melodic variations.

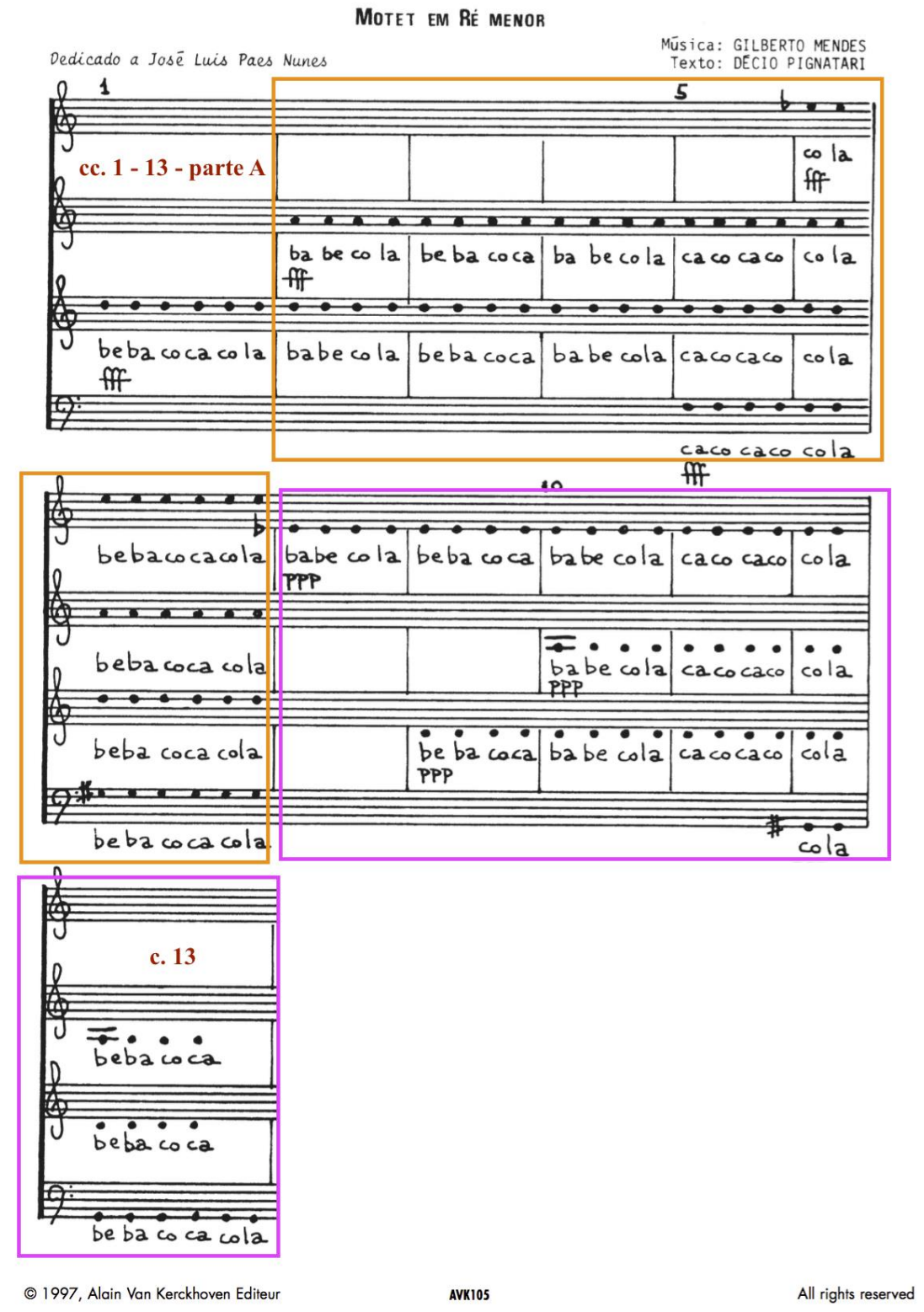

Example 3: Two blocks on the first page of the Motet 
In measure 15, soprano, contralto and tenor begin a modulatory move, with glissandos and vibratos, throughout three measures. This is an important moment because it introduces a densification of the melody based on addition of vibratos and effects of panning and spatialization. The bass line, however remains still, holding on its rhythmic precision during these three bars, in piano dynamic, producing a gradual distancing from the high voices.

\section{5}

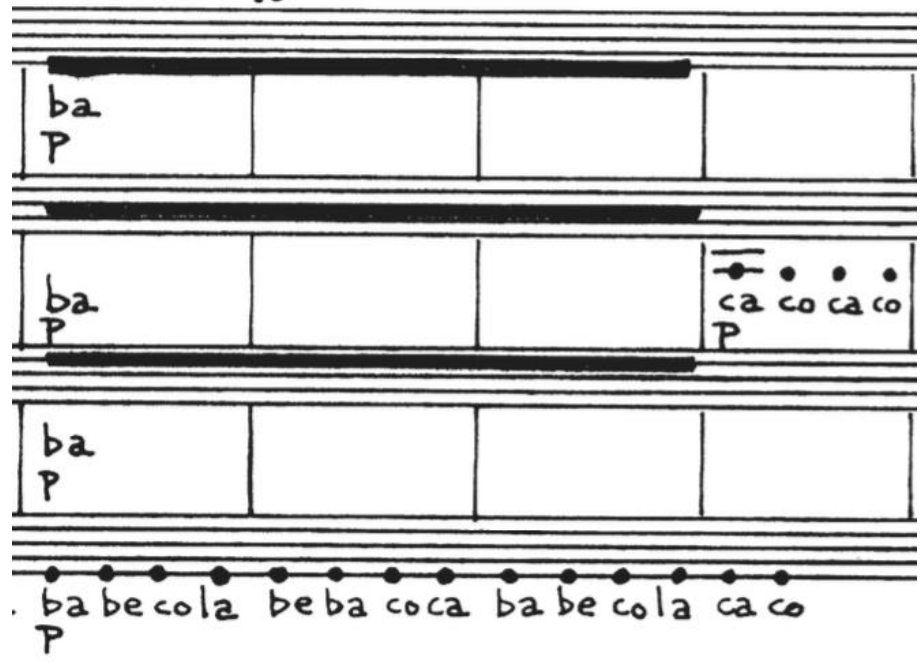

Example 4: measures 15-18

At measure 87, a long glissando serves as a sort of carpet - a denser and stratified layer - of timbre that will accommodate more incisive inclusions of the tenors and basses, uttering the words baba, babe and caco.

A burp, in our opinion, is the most peculiar moment of the piece. Not only it causes a rhythmic pause on the vocal orchestration, as it represents an anecdotal and critical figuration. The burp marks the beginning of the Coda, where Mendes imprints an important rhythmic change, through a rhythmic figure very common in Brazilian music: a quarter note between two eight notes, assigning a more stable and dancing pulse to the motet. This rhythm continues until almost the end of the piece, when Mendes constructs a sixteenth-note figure for babe cola, punctuated by pauses that create a final expectation of closure, with the three times repetition of the word cloaca (see Example 5). Pignatari's poem, as Gonzales (2005, p.109) states, "[...] leads to the term cloaca [...]", in a kind of consonant-yet-dissonant resolution of the rapid alliterations and quadruple organization and its homogenous form. 


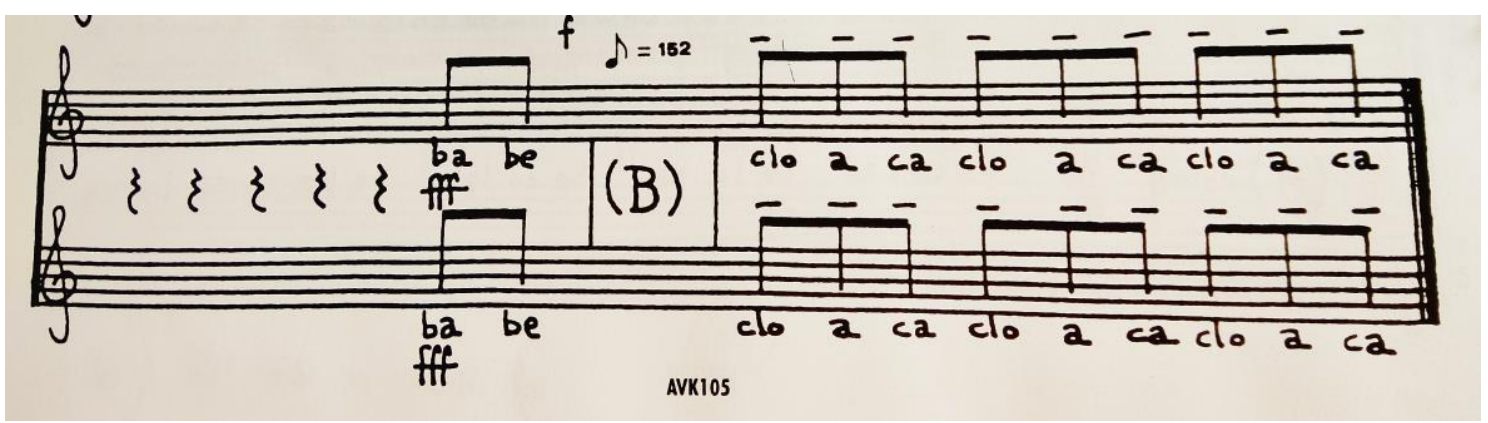

Example 5: Final Coda, with the word cloaca repeated 3 times

According to Mendes (2016, p.106), after the performance of the Motet by the Coralusp 8 at the International Festival of University Choirs in New York on April 25, 1972, the New York Times published a review that stated "the Brazilians thereupon got down to business, delighting the audience with such pop-flavored items as a Gilberto Mendes parody motet that urged everybody to drink CocaCola". This perception that the motet is just a parody is a superficial and decontextualized analysis. The author himself states (2016, p.107) that, "in fact, it is not a beverage advertisement, something that I would never do". The idea of anti-propaganda, quoted above, constructed by the composers as a critic who underlies the text, is one of the most important aspects in the composition of an original narrative, which sews the piece almost subliminally.

\section{4 - Intertextuality, Narrativity and Musical Meaning}

According to Grabócz (2009, p.87), musical signifiers can be "references to musical genres, topical, rhetorical-musical figures, texts implicit to instrumental music, recurrent materials in the same work or in different works of a composer". Concrete poetry uses the resource of repetition and periodization, among others, to assert a kind of "deterritorialization" of poetic discourse. As stated by Gonzalo (2005, p.64), "the activity of periodization is essential for the vanguards since they base their practices on the emergence of the New and self-legitimize [...] as a narration of the difference in repetition, the vanguards once again periodized the evolution of contemporary art". The repetition here, both in the original text of Pignatari and in the Motet of Mendes, is a functional feature. It is through repetition that both legitimize an artistic production that was creating a repertoire that had little or nothing to do with the artistic canon of the time. Repetition, as a function, is developed, unrolled, structured and often worked out from the idea of, as Campos $(2016$, p.23) states, a poem-plant, a kind of poetry

${ }^{8}$ Coralusp is a choral group of the University of Sao Paulo, Brazil. 
that grows on the blank space of the paper sheet and branches out through typographic resources.

Mendes leads the horizontality of his Motet using repetitions that revolve around the overcoming of verse-form, by contrast and differentiation, seeking to find a new minimal unit of the poem, through this amalgam and the fragmentations of the syllables. This piece uses at least part of the idea of paideuma $a^{9}$ proposed by the concretists, as did

Stéphane Mallarmé and his spatial and prismatic dispositions of the idea; James Joyce and his amalgam of words; e.e. cummings and his microscopic fragments; and Ezra Pound, both for his elaboration of traditions and the task of the translator as for his ideogram theory as a direct presentation of the images (Gonzalo 2005, p.66).

Listening to Mendes' composition, after reading Pignatari's poem, it is evident the strength of the cadencial rhythmic pace and, in opposition, when the acceleration of the rhythm comes, it implies an anxious narrative, typical of propaganda, where it is necessary not to leave the listener relaxed to think, or rather, it introduces a message that, seemingly engulfed by sounds, colors and other stimulating signs, the advertisement sales message is carried out. The words beba and the babe are insistently interspersed, almost metamorphosing the motet. What the original slogan wants to pass is the idea of buying Coca-Cola, consume Coca-Cola, spend your money with Coca-Cola, and Mendes understands this frenzy by rebuilding this capitalist ideological discourse through an incessant rhythm, perennial, continuous and incisive until the climax of a burp.

At the end of the poem put to music, there is the word cloaca, which contains all the letters that form the words cola, coca and caco. Pignatari and Mendes make clear an intention of eviction, of residue, where the syntactic result of formations - cola, coca and caco - could still suggest new words, such as calo and oca, for example. As Fernandes (1996, p.125) states:

Almost all words of the poem that can be formed with the letters of cloaca are impregnated with derogatory semantics, in which the denial of man and culture is evident. Thus, oca remembers a primitive state that is adapted to who is

\footnotetext{
9 Paideuma is a term used by Ezra Pound in some of his works. Apparentelly, Pound got the idea of paideuma from the German anthropologist Leo Frobenius. Pound wrotein his Machine Art and other Writings: the lost thought of the italian years (1996 edition, by Duke University Press), explaining the meaning of the Paideuma: "to escape a word or a set of words loaded up with dead association, Frobenius uses the term 'paideuma', for the single or complex of the inrooted ideas of any Period [...] the term has been given the sense of an active element in the era, the complex of ideas which is given time germinal, reaching into the next epoch, but conditioning actively all the thought and action of its own time ".
}

\section{MUSICA THEORICA}




\begin{abstract}
allowed to be influenced by strange cultures and imposed surreptitiously, through the coca. Even worse are the variant loca. If oca refers the nation to the pre-civilization stage, loca is rooted in an animal state, with potentialities for a type of domination that reduces it to the abject condition of an irrational animal. Inserted in this ideology, the word calo - that could embody the exercise and practice of daily work, shifts the semantic field to the vile silence of submission, proper to those who do not have the cry embedded in the forms of culture. Finding himself in a slave state, because he is subjugated culturally, he becomes repellent, which causes disgust, nausea, as can be deduced from another possible word composed with the cloaca phonemes: aca, that which produces bad smell, because it is deteriorated. To this people, seen from this point of view, nothing remains but the cloaca.
\end{abstract}

It may be pertinent to recall that one of the modern poets who are very influential to the concretists but who, for reasons never elucidated, is outside the paideuma group instituted by the movement, is Vladimir Maiakovsky (1893-1930). It seems to us that Mendes reallocates the rhythmic force of the alliterations of the Russian poet, aiming the force of the repetition resource of the Maiakovski's poem Balalaika, from 1913, translated by Augusto de Campos:

\author{
[budto laiem oborvala \\ scrípkibala \\ laica] \\ [s laiem oborvala] \\ oborvala [s laiem] \\ [láiki bala] \\ láicu bala \\ laica
}

(Maiakovski, 1913)
[como um balido abala
a balada do baile
de gala]
[com um balido abala]
abala [com balido]
[a gala do baile]
louca a bala
laica

(Translation of Augusto de Campos) 
The balalaika $a^{10}$ - a traditional three-string Russian musical instrument - is an instrument that dates back to ancient times, but had a strong penetration in popular folk music between the 17th and 19th centuries in Russia / North East. With a wooden body built with a triangular shape and having different sizes and types, its three strings, played with a kind of wood or bone pick, enable the construction of melodic material easily standardized by strong repetitive rhythmic accentuation. The poem of Maiakovsky brings this characteristic very clearly. The translation of Augusto de Campos turns this feature yet more prominent. We perceive the strong rhythmic characterization that the phrase possesses, when fragmented:

\section{"como um balido aBala a Bala - da do baile de Gala"}

Here, we can see/listen to a strong intertextuality when the translation of Balalaika reverberates in Mendes' Motet. We perceive the rhythmic force that the repetition of the syllable causes reading it aloud. It immediately sends us from the text of Beba Coca-Cola, to the audition of the Mendes's Motet, that allocates a strong pulsation on the syllables $b e, b a, c a$ and $c o$. From the idea of a pick attack on the strings of an instrument like the balalaika, appears the ability to incorporate a rhythmic figuration that could be transcribed as in Example 6.

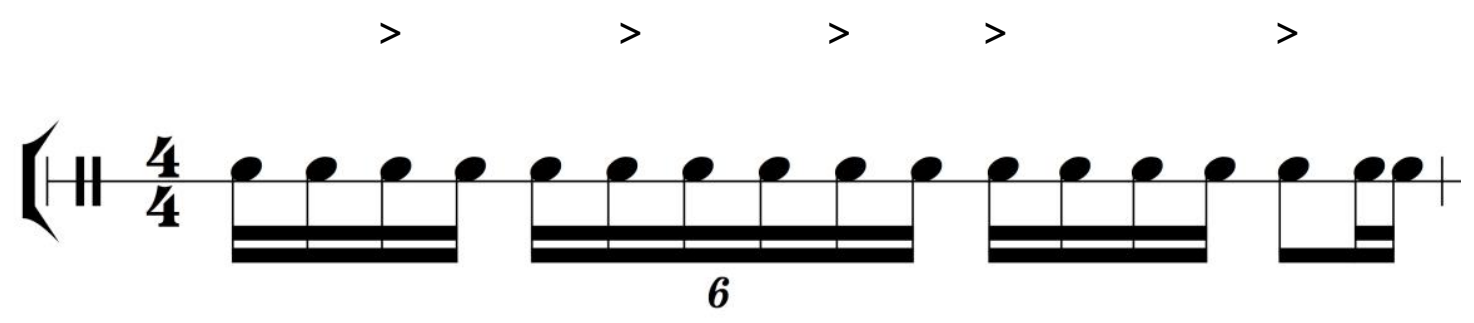

Example 6: Rhythmic idea from the first lines of Maiakovsky's poem Balalaika, translated to Portuguese by Augusto de Campos, present also in Mendes's Motet.

The interpretation of Motet em Ré Menor by choral groups in different parts of the world has allowed theatrical actions during its performance, from a verbivocovisual point of view. In 1990, during a performance to record an album of Mendes' music, during the Ein Abend der Brasilianischen Musik, by the Kammerchor der Humboldt-Universität zu Berlin, directed by Johanner Garbe, at the end of the performance of the piece, when the word cloaca is repeated 3 times, some of the members of the choir raised three times cardboard signs with the

${ }^{10}$ See: http://balalajka.dk/en/instrumenter/balalajkaens-historie/- access on June 28, 2017. 
letters C-L-O-A-C-A, horizontally juxtaposed (see example 7). In another performance, by Cobra Coral, in Rio de Janeiro, directed by Marcos Leite, arriving at the same point of the Coda, instead of a banner or posters with the lyrics, six female singers raised their blouses showing their breasts. The letters of cloaca were printed on the back of their shirts.

Motet has achieved a large impact on audiences over the years because it is a mixture of parody and criticism. It is a choral piece that points out ways of interpretation and performance with the use of syllables, vibratos, onomatopoeia, vowel sounds originating from popular speech, belching, etc. The dialectical tension present in the Motet seems to be arranged and reconfigured during its performance, becoming a kind of vehicle for agglutination between different signs, building a unique aesthetic capable of multiple meanings.

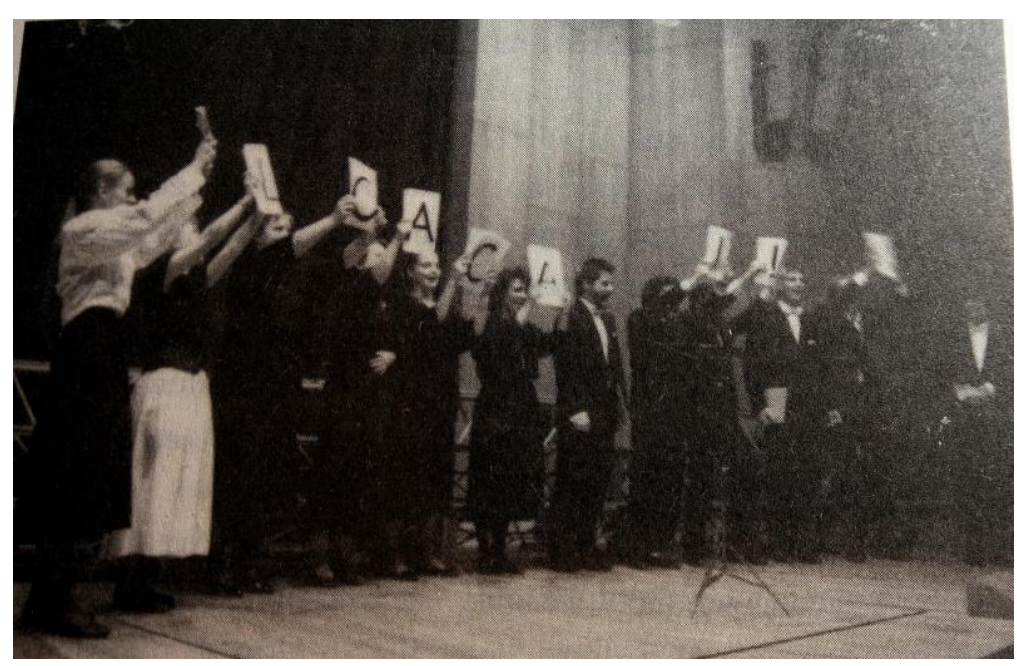

Example 7: Performance of Beba Coca-Cola by the Kammerchor der Humboldt-Universität zu Berlim, 1990

In terms of topic, let us raise a question posed by Agawu (2008, p.3): Does music have a meaning? This question has been asked for centuries. Indeed, it considers implicitly that a musical work can carry a narrative discourse. The interpretation of this narrative can be broad and, at the same time, unique. Agawu himself states that meanings are contingent, and the author clarifies, shortly after (2008, p.15), that "music's contexts are many, probably infinite [...] Music frequently transgresses borders and seems uniquely placed among the arts to do so". This process of individuation, which refers to the senses and affects that are proper to the human being, is based on knowledge, experience, cultural immersion and subjective characteristics. Moreover it is substantially enlarged when exposed to a musical composition and its possible meanings. As Barthes 
writes (1967, p.10), "to think and talk about music is-necessarily, it would appear-inevitably to fall back on the individuation of a language".

Motet em Ré Menor can be interpreted, concerning the use of topical meaning, according to the individuation process mentioned above that applies one of the principles proposed by Agawu (2008, p.27): "a musical composition, like a verbal composition, is organized into discrete units or segments. Music is in this sense, segmentable". Thus, after a segmentation of an organized horizontal time-line, we identified some topics on Mendes's composition following characteristics recognized by Grabócz (2010), Agawu (2008), Caplin (2005) and Klein 2010). The topics are:

- Recitative

- Ironic style

- Buffa style

- Chorale

- Popular style

- Singing style

- Parody

- Pathetic style

- Declamatory style

- Quotations

- Circus music

- Chaconne

It is clear to me that Mendes's composition permeates the listener with a semiotic quality described by Klein (2010, p. 104-105) that relates to the four basic types of tropification ${ }^{11}$ : metaphor, metonymy, synecdoche and irony, but mainly to the characterization of comedy, sarcasm and irony. The onomatopoeic vocalization on the letter Aaaaaaaaa..., that initiates on $\mathrm{m}$. 24, or in the long glissando that begins on measure 87, exemplify tropes of extreme satirical character, lasting for several measures (more precisely, until measure 125). Using sarcasm and irony, detachment from formalism and even an aesthetic rupture with the space of the Italian stage, Mendes sews an interpretation of Pignatari's poem that approaches several ruptures with the traditional plan of a motet. Nevertheless, the composer structures his composition with well-founded and organized musical elements. From the poem of Pignatari, the composer - almost literally - translates the signs of concrete poetry on sounds, creating a short but at the same time, structurally dense piece, through a sensory process that

\footnotetext{
${ }^{11}$ Robert Hatten (2004) refers to tropification as an important process in which composers can join and agglutinate different (similar or opposing) topical characteristics in a single expressive material, thereby creating new meanings.
} 
interweaves words, sounds, letters, symbols, listening, breathing, and synesthetic sensations. As Coelho de Souza says about synesthesia (2016, p.2), "the senses (of perception) and the senses (of language) intertwine in ways that we do not yet know". Mendes' piece explores this uncharted territory of new sensorial experiences. Even a simple tropification initiated on measure 128 (Example 8), composed with the ideas of sudden cavalcade, wilderness and backland expeditions seems to agglutinate the composition in a very peculiar way, unique, permanent, rightly made. Unexpectedly it suggests to us a reference to Guimarães Rosa's Grande Sertão, Veredas. Mendes not only composes, but also orchestrates, at the same time, the musical, sonorous and linguistic attributes of his Motet.

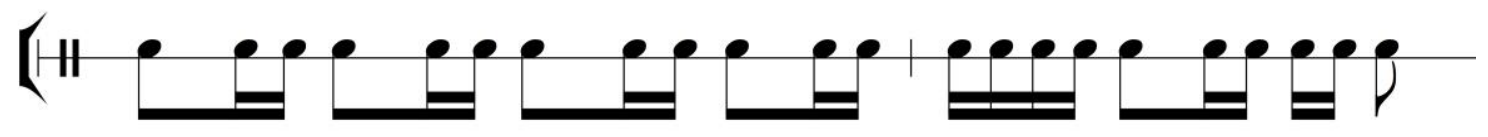

Example 8: Tropification: cavalcade and characteristic gallop rhythm, Coda, m. 128

\section{5 - Conclusion}

The composition of Motet em Ré Menor was a landmark on the 1960's Brazilian avant-garde movement with key elements for the understanding of how an innovative poetic text can encompass intertextual relations with new conceptions in the field of sound studies, performance and musical composition. The narrative, that we imagine was proposed by Mendes, shows a flow of signs, similar to Haroldo de Campos' Galáxias, in which, as Gonzales (2005, p. 112) states, "the poetic sign [reaches] the limit: they interfere in orality, travel the world and languages, go in search of social and artistic events".

Compared to the almost rigid structural framework that rules Pignatari's original poem, Mendes's motet proposes a somewhat more open - and perhaps freer - narrative. It descends from an evolutionary lineage that reaches the Brazilian postmodern environment of the second half of the XXth Century. Works in the field of literature, and arts in general, such as those of João Guimarães Rosa, Oswald de Andrade, João Cabral de Melo Neto, Glauber Rocha, Adélia Prado, Ferreira Gullar, Darcy Ribeiro, Lina Bo Bardi, Helio Oiticica, Antônio Bandeira, Alfredo Volpi, Lygia Clark, Claudio Santoro, Camargo Guarnieri, Guerra Peixe, among others, are the companions of Mendes's journey.

By encompassing different artistic modalities, synthesizing the creative spirit of his time, Motet em Ré Menor ends up creating a kind of meta-narrative, which combines visceral traits between literature, concrete poetry, visual arts, cinema, architecture and contemporary music. In other words, Mendes develops 
a meta-linguistic enunciatively praxis of narrativity, where signs tend to be polysemic, open to personal interpretation. We can observe this experience as a gestalt process that combines proximity, resemblance, continuity and common movement of individual experience.

This short analysis of Motet em Ré Menor intended to demonstrate how the composer proposed the sound experience for the listener as an individual, unique journey, notwithstanding other common links to his or her world. Despite our analytical bias for poetic and musical meaning, we claim that the composer's approach to composition was inspired by the concepts of narrativity and intertextuality.

\section{References}

1. Agawu, Kofi. 2008. Music as discourse - Semiotic adventures in Romantic Music. New York: Oxford University Press.

2. Coelho de Souza, Rodolfo. 2016. Sinestesia como condição para linguagem: uma conjectura. Curitiba: Revista Percepta. Associação Brasileira de Artes e Cognição Musical, ed. 3, vol. 2, p. 17-32.

3. Correa, Thiago M. 2011. Análise de "Pós-tudo": metalinguagem na poesia concreta. Revista Estudos Semióticos vol. 7, n. 2, p. 63-69.

4. Deleuze, Gilles; Guattari, Félix. 1993. A Thousand Plateaus. Minneapolis: University of Minnesota Press

5. Due, Andreas R. 2007. Deleuze. Cambridge: Polite.

6. Fernandes, José. 1996. O poema visual: leitura do imaginário esotérico (da antiguidade ao século XX). Petrópolis: Editora Vozes.

7. Grabócz, Márta. 2009. Musique, Narrativité, Signification. Paris: Ed.: L'Harmattan.

8. Klein, Michael. 2010. Ironic Narrative, Ironic Reading. Baltimore: Journal of Music Theory, vol. 53, p. 95-136. 
9. Magre, Fernando de Oliveira; Berg, Silvia Maria Pires Cabrera. 2015. Estratégias para a performance de música contemporânea com coros amadores: Beba Coca-Cola de Gilberto Mendes e o Coro Juvenil da UEL. Vitória: Anais da XXV Anppom.

10. Mendes, Gilberto. 2016. Uma Odisséia Musical - dos mares do sul à elegância pop/art déco. São Paulo: Edusp.

11. 1997. Motet em Re Menor - for mixed choir. Partitura.

Brussels: The New Consonant Music.

12. Menezes, Flo. 1998. Atualidade Estética da Musica Eletroacústica. São Paulo: EDUSP.

13. Pignatari, Décio; Campos, Augusto de; Campos, Haroldo de. 1975. Teoria da Poesia Concreta. São Paulo: Duas Cidades.

14. Santos, Antonio Eduardo. 1997. O antropofagismo na obra pianística de Gilberto Mendes. São Paulo: Annablume/Fapesp. 